\title{
EVALUATION OF DISTANCE LEARNING POLICY DURING THE COVID-19 PANDEMIC IN ELEMENTARY SCHOOL
}

\author{
Gilang Ramadhan ${ }^{1}$, Luthfiah Andriliani ${ }^{2}$, Ina Magdalena ${ }^{3}$ \\ ${ }^{1,2,3}$ Elementary Education Study Program, Universitas Muhammadiyah Tangerang, Indonesia
}

\section{Article Info}

Article history:

Received: $15-12-2021$

Revised: 21-12-2021

Published: 31-01-2022

\section{Keywords:}

Learning Evaluation

Covid-19 pandemic

2013 Curriculum

ABSTRACT

This study aims to determine the implementation of learning evaluation at SDN Poris Pelawad 1, Tangerang City. The research method used is a qualitative method with descriptive data exposure. Data collection techniques using interviews, observation, and documentation. Sources of data collection were obtained from sources/informants and from the research site. The results of this study are that the evaluation of distance learning policies at SDN Poris Pelawad 1 has been carried out quite well. This school has used the 2013 curriculum, so for its evaluation it must meet three domains, namely the realm of knowledge, attitudes and skills. This study uses an interview method to one of the teachers of SD Negeri Poris Pelawad 1. The interviews were conducted directly/offline by approaching the resource persons.
\end{abstract}

This is an open access article under the CC BY-SA license.

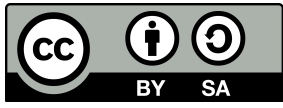

\section{Corresponding Author:}

Gilang Ramadhan,

Elementary Education Study Program, Universitas Muhammadiyah Tangerang,

J1. Perintis Kemerdekaan I/33 Babakan, Tangerang, Indonesia

Email: gilangggr18@gmail.com

\section{INTRODUCTION}

The Ministry of Education made a new policy through SE number 4 of 2020 regarding the implementation of education policies during the emergency period of the spread of Corna virus Disease (Covid-19). The content of one of the policies is to enforce the learning process from home through online/distance learning. Basic Education Response to Distance Learning Policy During the Covid-19 Pandemic at SDN Poris Pelawad 1, Tangerang City. Distance learning is the option chosen to provide learning and training to students who cannot gather or in groups due to several obstacles, one of which is aimed at minimizing the transmission rate from the Covid-19 pandemic in Indonesia which is still high. This option is the best option chosen by the government to prevent transmission, but the learning process can still take place. It is also expected to be able to provide a meaningful learning experience for students, without being burdened with completing curriculum achievements for grade promotion and graduation. This distance learning policy is implemented at all school levels, from PAUD to tertiary institutions. The schools most concerned about transmission are schools at the elementary level, namely SD/MI and SMP/MTs because of the large number of schools and students in every region in Indonesia. In addition, basic education students are still considered not to understand how to protect themselves from transmission and do not understand how to do social distancing according to the health protocols that have been made by the government.

Schools are also considered not able to monitor every movement of students and provide facilities that are in accordance with social distancing standards. Therefore, the best option is to do distance learning 
(PJJ). The Minister of Education himself has announced that he will extend distance learning activities because he sees the rate of virus transmission in Indonesia which is increasing day by day, then after the new normal or new normal conditions were implemented, the rate of virus transmission is increasing. This has caused considerable concern for the government, especially the ministry of education. The Distance Learning System (PJJ) is planned to continue until 2021. Distance learning (PJJ) is a form of learning that is not connected (separate students, teacher-students) and provides the opportunity for each to learn separately. However, it is always provided or attempted to make a meeting between teachers and students which is only done when there is a special event or or there are certain needs. Dogmen in Jerusalem, et al (2015) The hallmark of distance learning (PJJ) is the existence of an institution or organization that regulates how the learning system runs independently, the material delivered is through the media without having to meet each other. institutions are also expected to be responsible at the highest standard level for distance learning programs (PJJ), crisis management is needed so that institutions can be better prepared in dealing with crises and reduce their impact so that the learning process and managerial activities can continue to run productively (Murfi, Fathurrochman, Atika, \& Saiva Jannana, 2020).

Learning through networks has potentials, including: ease of access, meaningful learning and increased learning outcomes. Through online learning will also create a modern learning environment. Teaching and learning processes can still be carried out properly thanks to the help of advances in information technology which is currently very advanced. The effectiveness of teaching and learning is still carried out with the help of the internet 310 and applications to make it easier to interact properly (Nasution, 2020). Abidin, et al. (2015), stated that the project-based online learning system provides many opportunities to access teaching materials by learning citizens. There are many online media and online platforms that can be accessed via the internet by students and teachers.

The process/system in distance learning (PJJ) can be used as initial capital for prospective teachers in carrying out their learning in the future and with a distance learning system can still provide good access to reach students. The advantage of this distance learning system is that it can be done anywhere, it can also improve the ability of teacher-student interactions, can reach a fairly wide range of students and then provide convenience in the process of delivering material and storing material. During the Covid-19 pandemic, educators such as teachers are required to understand all methods or procedures for implementing online teaching in the Distance Learning (PJJ) process. These educators have the main task of working including as teaching staff for students, as people who are responsible for providing material and carrying out other tasks assigned by the government.

Teachers at schools carry out two main tasks, namely providing planning and assessing the results achieved by students during the learning process. So, it is hoped that teachers will be able to provide suitable learning methods during the pandemic. Meanwhile, students are the object of acceptance in the implementation of Distance Learning (PJJ). Students will accept and apply directly any method or learning model that is given or delivered. In the learning method that has begun to be applied with the PJJ system, it will certainly affect the acceptance aspect of students. Students are also expected to have an awareness that home learning activities are an obligation that must be carried out. The roles and responsibilities of parents are also very important. On the other hand, the anxiety, sadness, boredom felt by students will definitely appear, so parents are expected to be able to provide internal reinforcement for students. From several observations regarding the distance/online learning process, several problems were also found, such as aspects of the obstacles to implementing distance learning programs, namely pedagogical, technological and economic aspects (Nurkolis \& Muhdi, 2020).

In terms of pedagogy, not all online learning implementation processes have been successfully implemented, due to the limitations of the learning environment and the characteristics of (Dewi, 2020). Then from the technological aspect, not all teachers and students can use direct and smart applications with laptop or mobile devices, from the economic aspect, it is very necessary to support devices such as laptops or cellphones to connect to the internet and other problems such as the lack of interest in student learning due to changes in the learning atmosphere and others. SDN Poris Pelawad 1, Tangerang City has also implemented distance learning activities (PJJ). Almost all schools starting at the elementary and secondary levels, schools have implemented an online learning system. From the 311-implementation process that has taken place during the pandemic, I really want to know what things can be found at SDN Poris Pelawad 1, Tangerang City, regarding the process of applying distance learning (PJJ).

Both from the principal, teachers and students. Therefore, the author is interested in writing an article that aims to see the Response of Elementary and Middle Level Schools to the Distance Learning Process During 
the Covid-19 Pandemic at SDN Poris Pelawad 1, Tangerang City. The formulation of the problem from this research is how the elementary school response to the distance learning process is. To understand more deeply about policy evaluation in the learning process, this report will discuss the theory of learning policy evaluation, the results of observations on the evaluation of learning policies at SDN Poris Pelawad 1, as well as analysis of observations. The results of observations and interviews with Mrs. Pipit Sumanti S. Pd, as a teacher of mathematics subjects at SD Negeri Poris Pelawad 1, the principal, and parents of students.

\section{RESEARCH METHOD}

This research is a descriptive study with a qualitative approach, the analysis is carried out by looking at the percentage distribution of each measurement aspect. The research was conducted on Tuesday, January 19, 2021. The research was conducted by distributing online forms to respondents. This study also uses a Classroom Action Research (CAR) design. CAR comes from problems found by the teacher during class learning activities. CAR is a research carried out by teachers in their class which has the intention to improve and improve the quality of learning in the classroom. With this research, teachers can detect the weaknesses experienced by students and take action to deal with student problems. This research was conducted with the hope that teachers can reflect on the educational services that have been provided to students so that they can improve the quality of learning in school institutions.

Classroom Action Research has several characteristics, namely:

1. In terms of problems, the characteristics of CAR are problems that are raised from problems of practice and the daily learning process in the classroom that are really felt directly by the teacher.

2. Classroom Action Research always departs from the teacher's critical awareness of the problems that occur when learning practices take place, and the teacher realizes the importance of finding solutions to problems through actions or actions that are planned and carried out as carefully as possible in scientific and systematic ways.

3. There is a plan of certain actions (actions) to improve practice and the learning process in the classroom.

4. There is a collaborative effort between the teacher and other colleagues (teachers or researchers) in order to help observe and formulate basic problems that need to be addressed.

Classroom action research (CAR) is a controlled investigation process to find and solve learning problems in the classroom, which is carried out cyclically, with the aim of improving the quality of the learning process and outcomes in certain classes. The main characteristics of CAR are:

1. The problem comes from the setting/class where the research is conducted.

2. The problem-solving process is carried out in a cycle.

3. The goal is to solve learning problems in the classroom or improve the quality of learning in the classroom

This CAR will use research in a cycle. Researchers designed 2 cycles. If the results of the research in cycles I and II have not reached the maximum results, a research will be held in the next cycle. This research will apply the CAR procedure developed by Kemmis and Mc Taggart. The stages in this research include 3 stages, namely:

1. Planning

2. Treatment

3. Observation

4. Reflection

At the planning stage, the researcher made direct observations to the research location and conducted questions and answers to the class I teacher at SDN Poris Pelawad 1, Poris Pelawad Utara Village, Tangerang City. Observations were carried out by researchers by observing and recording the learning evaluation of students at SDN Poris Pelawad 1. The data were obtained through interviews, observations, and document studies. Analysis of the data used in this study using factual analysis. The factual analysis means analyzing knowledge about detailed, specific facts and statements that are true because they are in accordance with the circumstances. Interviews conducted with resource persons from SDN Poris Pelawad 1.

\section{RESULT AND DISCUSSION}

PJJ Respondents Respondents from this survey included school principals, teachers, students and parents of students who were randomly selected with a fairly strong level of trust. PJJ's Policy for the Implementation of Distance Learning It can be seen from one of the question instruments, namely "Has the school 
implemented a Distance Learning program?" $99.4 \%$ of the respondents, namely principals and teachers, stated that they had implemented a learning program using the Distance Learning (PJJ) method. This is because during the current pandemic, it is necessary for every school to conduct online teaching and learning processes to avoid the spread of Covid-19 in schools. The effectiveness of distance teaching and learning can still be implemented with the help of the internet and applications to facilitate good interaction. Applications and gadgets are needed to connect to the internet, not all educators and students can use the application directly and mingle with gadgets.

Then some of the respondents stated that they did not do PJJ. Respondents who stated no, stated that the learning program implemented was by visiting students one by one and by giving students assignments and questions via WA or contacting parents. However, only a few respondents gave this response. Support for School Regulations Of the majority of schools that implement Distance Learning (PJJ), some of these schools also state that they have regulations to support home learning programs. The principal respondents gave responses regarding support stating $88 \%$ yes, and $12 \%$ stating no. PJJ In this case it can be seen that schools have set regulations in accordance with the direction of the Ministry of Education and Culture. Support from parties related to distance learning programs is needed, When schools are asked to be responsible at the highest standard level, strong leadership is very important for school success, crisis management is needed so that schools can be better prepared to face crises and reduce their impact so that the learning process and managerial activities can still run productively.

School Budget Adjustment Judging from the principal's respondent data, in general schools have adjusted their budget allocations to support the Distance Learning (PJJ) process. From several respondents, principals stated that they had made budget adjustments. In accordance with PERMENDIKBUD number 19 of 2020 regarding flexibility in the use of BOS funds, schools, both principals and teachers, were indeed given the flexibility to manage school budgets and use them as well as possible to support the learning system during the pandemic. Activities in Distance Learning Implementation Learning. Method of Implementation of PJJ From the data that has been filled in by the respondents, it was found that most of each teacher suggested that they had implemented the Distance Learning Program (PJJ). When viewed from the process of providing material, the teacher stated yes, various learning methods were given through various alternatives such as reading and then providing material, using applications that support creativity, asking students to learn to grow their character and creativity, asking students to make practical video tutorials to distributing material through WA application. However, of the many learning methods provided, the most is by reading and then summarizing the material.

The results of the survey can be seen below: By providing a teaching method by reading and then summarizing the material the teacher feels is sufficient to help students better understand the subject of learning then this can also provide many opportunities for students to access other teaching materials. There are many platforms and online media that can be accessed via the internet by teachers and students. Forms of Support and Communication Facilities Support of facilities and infrastructure is the greatest form of support given by various parties in carrying out the learning process from home. In addition to this form of support, the teachers also stated that they received mentoring training support. The means of communication used by teachers during learning are through WA, SMS, Google Classroom, zoom and other supporting applications. As it is known that WA and zoom applications are the best and most widely applied applications, for zoom applications apart from being a service that can cover more participants, face-to-face learning applications are also more effective at using zoom, for task sharing applications, the most popular application is WA and google classroom.

Online learning demands the role of educators to evaluate effectiveness and adapt to learning needs. This is important to do to keep fulfilling aspects of learning such as the process of knowledge, morals, skills, intelligence and aesthetics. Given that the change to online learning indirectly affects the absorption of students (Dewi, 2020). It is important to note that the communication between parents and educators is to realize the independence of students' learning during the COVID-19 pandemic. The various benefits obtained, of course, have obstacles that are felt by educators and students in online learning. The obstacles faced are the various regional conditions in Indonesia, causing not all areas to be reached by internet services and the distribution of internet networks is slow at any time. It also allows high internet usage to affect the health of students. Another obstacle found was the ability of parents to provide online education facilities such as the use of the internet network which requires a fee. Adjustment of Curriculum Completeness Most of the teachers in schools still carry out learning in accordance with the existing curriculum. Despite being in the Covid pandemic situation, this is still being done by the teachers. This is in accordance with the SE of the Ministry of Education and Culture number 4 of 2020 regarding the implementation of education during the Corona Virus Disease (Covid- 
19) emergency.

The same thing was also stated by Yerusalem, et al. (2015), that the implementation of the Distance Learning curriculum (PJJ) has been loaded and adapted to each subject. Student Responses for the Implementation of Distance Learning From the student respondents accepted by most of the students stated that they had carried out the learning process at home during the Covid-19 pandemic. From the survey it was also found that students stated that they were very happy with the learning process at home, this is because students feel quite relaxed, not noisy and can while enjoying the food. Then the response stated that they were not happy. This is because students cannot meet each other with friends or teachers, then students feel the learning system is less effective and students do not understand the lessons given by the teacher. Trials of the application of learning methods to students can be carried out effectively because of various obstacles such as the lack of supporting communication facilities such as cellphones, poor networks, parents who are less able to operate cellphones and assignments that not understood by students.

Constraints Facing Students. Students' Main Constraints during the Implementation of PJJ Judging from the data received, the most important obstacle felt by students was the lack of quality internet connection and the lowest was not having a mobile phone. These constraints are the factors that make learning activities at home less than optimal. Based on various studies, the main obstacle is indeed a bad connection disorder, it really disturbs the concentration of participants who carry out the online learning process. Parental Responses According to respondents who are all parents of students, $100 \%$ said that their children have fully implemented the Distance Learning (PJJ) process and parents are still actively involved in helping students learn. The form of support is in the form of assistance in directing students to do assignments in accordance with the directions given by the teacher. Then according to most parents, they were given instructions by the teacher and felt no burden to help students in the learning process at home. However, some stated otherwise, because according to parents some of their main tasks were becoming constrained, then children still did not understand the teacher's explanations, limited supporting facilities and increased costs related to buying internet quotas.

\section{CONCLUSION}

New developments in the view of teaching and learning implementation have consequences for teachers to increase their roles and competencies, because the teaching and learning process and student learning outcomes are largely determined by the role of competent teachers. Competent teachers will be better able to create an effective learning environment and will be better able to manage their classes, so that student learning outcomes are at an optimal level. One of the teacher's roles in the teaching and learning process is as an evaluator. In one teaching and learning process the teacher should be a good evaluator. This activity is intended to determine whether the objectives that have been formulated have been achieved or not, and whether the material being taught is quite appropriate. All these questions will be answered through evaluation or assessment activities.

First, from the school side, they have implemented the Distance Learning (PJJ) program, second from the teacher side, the most widely applied learning method by teachers is the reading method and then summarizing the material. However, it was found that the 3 biggest obstacles implemented by the teacher were (limited supporting facilities, learning management skills, use of digital media. Third, from the students' side, they stated that they really enjoyed Distance Learning (PJJ) activities while others did not like it. This is because students have several main obstacles, namely lack of connection quality and internet quota, limited communication devices such as laptops and cellphones, students' lack of understanding with the various applications offered, and fourth from the parents side stated that they did not feel burdened with children studying at home, on the grounds that they could help children in guiding and get closer to them. child.

\section{REFERENCES}

Ariin, Z. (2015). Evaluasi Pembelajaran. Jakarta: Direktorat Jenderal Pendidikan Islam Kementerian Agama RI.

Dewi, W. A. F. (2020). Dampak COVID-19 terhadap Implementasi Pembelajaran Daring di Sekolah Dasar. EDUKATIF : JURNAL ILMU PENDIDIKAN, 2(1), 55-61. doi:10.31004/edukatif.v2i1.89

Murfi, A., Fathurrochman, I., Atika, A., \& Saiva Jannana, N. (2020). Kepemimpinan Sekolah dalam Situasi Krisis Covid-19 di Indonesia. MANAGERIA: Jurnal Manajemen Pendidikan Islam, 5(1), 119-136. doi:10.14421/manageria.2020.51-07 
Nasution, M. (2020). Covid-19 Tidak Menjadi Hambatan Pendidikan di Indonesia? doi:10.13140/RG.2.2. 28543.36005/1

Nurkolis, N., \& Muhdi, M. (2020). Keefektivan Kebijakan E-Learning berbasis Sosial Media pada PAUD di Masa Pandemi Covid-19. Jurnal Obsesi : Jurnal Pendidikan Anak Usia Dini, 5(1), 212. doi:10.31004/ obsesi.v5i1.535

Yerusalem, M. R., Rochim, A. F., \& Martono, K. T. (2015). Desain dan Implementasi Sistem Pembelajaran Jarak Jauh Di Program Studi Sistem Komputer. Jurnal Teknologi dan Sistem Komputer, 3(4), 481. doi:10. 14710/jtsiskom.3.4.2015.481-492 